\title{
L'Art Français et Francophone depuis 1980 / Contemporary French and Francophone Art, a cura di Michael Bishop e Christopher Elson
}

\section{Maria Chiara Gnocchi}

\section{(2) OpenEdition \\ 1 Journals}

\section{Édition électronique}

URL : http://journals.openedition.org/studifrancesi/28108

DOI : $10.4000 /$ studifrancesi.28108

ISSN : 2421-5856

Éditeur

Rosenberg \& Sellier

\section{Édition imprimée}

Date de publication : 31 décembre 2006

Pagination : 641

ISSN : 0039-2944

\section{Référence électronique}

Maria Chiara Gnocchi, «L'Art Français et Francophone depuis 1980 / Contemporary French and Francophone Art, a cura di Michael Bishop e Christopher Elson », Studi Francesi [En ligne], 150 (L | III) | 2006, mis en ligne le 30 novembre 2015, consulté le 08 novembre 2020. URL : http://

journals.openedition.org/studifrancesi/28108; DOI : https://doi.org/10.4000/studifrancesi.28108

Ce document a été généré automatiquement le 8 novembre 2020.

\section{c)}

Studi Francesi è distribuita con Licenza Creative Commons Attribuzione - Non commerciale - Non opere derivate 4.0 Internazionale. 


\title{
L'Art Français et Francophone depuis 1980 / Contemporary French and Francophone Art, a cura di Michael Bishop e Christopher Elson
}

\author{
Maria Chiara Gnocchi
}

\section{RÉFÉRENCE}

L'Art Français et Francophone depuis 1980 / Contemporary French and Francophone Art, a cura di Michael BISHOP e Christopher ELSON, Amsterdam-New York, Rodopi, «Faux Titre», 2005, pp. 238.

Ce volume publie les travaux d'un colloque international qui a eu lieu en 2001 à la Dalhousie University. Né et conçu au Canada et en Acadie, le livre est bilingue, français et anglais (y compris la préface!), même si les articles écrits en français sont nettement majoritaires. Les 23 contributions se fondent sur des approches critiques très différentes, et s'attachent à des sujets (pratiques et conceptions) également disparates, bien que toutes hypercontemporaines. 